\title{
Ocean $\mathcal{G}$
}

Coastal

Management

\section{Sand barrier development in the bight of Benin, West Africa}

\author{
Adoté Blivi $^{\mathrm{a}, *}$, Edward J. Anthony ${ }^{\mathrm{b}}$, Lucien M. Oyédéc \\ ${ }^{a}$ Department of Geography, Faculty of Letters et Human Sciences, University of Benin, \\ Lomé BP 1515, Togo \\ b Départment de Géographie, Université du Littoral 'Côte d'Opale', 2 Chaussée des Darses, \\ F-59/40 Dunkerque, France \\ c Départment de Géologie, Université Nationale du Bénin, B.P. 526, Cotonou, Benin
}

\begin{abstract}
The morphology, sedimentary facies, stratigraphy and development history of re-entrants and sand barriers in Togo and Benin (West Africa) have been analysed from boreholes and field data, and available radiocarbon dates. Re-entrant deposits range from basal Late Pleistocene fluviatile sands into Holocene estuarine and fluvio-deltaic sands. As sea level stabilized between 6000 and 5500 B.P., the "compartmented" coast associated with these reentrants favoured a polycellular longshore drift system. As the latter became infilled throughout the bight of Benin between 6000 and 4000 B.P., the littoral drift system evolved into a unicellular system fed by the Volta delta in Ghana, which has been the major sand source for an almost $300 \mathrm{~km}$ long outer barrier. In spite of the massive and consistent volume of sand drifting eastward $\left(1.2-1.5 \times 10^{6} \mathrm{~m}^{3} / \mathrm{yr}\right)$, progradation slowed down or ceased as equilibrium was achieved between coastal/shoreface geometry and the hydrodynamic regime, resulting in a balance between incoming and outgoing sand, and the downdrift migration of the accumulation sector towards Nigeria. This situation was probably achieved around 1500 to 2500 years ago in Benin, but apparently occurred much earlier in the updrift sector in Togo. This stability has been perturbed by the construction of deepwater ports in 1962 in Cotonou and 1967 in Lomé leading to segmentation of the unidirectional drift and spectacular progradation and erosion, respectively, updrift and downdrift of breakwaters. (C) 2002 Published by Elsevier Science Ltd.
\end{abstract}

*Tel.: + 228-221-68-17; fax: + 228-221-85-95.

E-mail addresses: adoblivi(a)hotmail.com (A. Blivi), anthony@univ-littoral.fr (E.J. Anthony). 


\section{Introduction}

The study of clastic coastal deposits has undergone fundamental changes in the last two decades (1975-1995) with the development of stratigraphic, morphosedimentary and morphodynamic models. Progradational systems such as sand barriers and associated backbarrier deposits have had a fair share of this research. Globally associated with wave-dominated and mixed wave/tide-dominated environments [1], the morphology, facies associations, stratigraphy and dynamics of these deposits are also conditioned by sea level, antecedent topography or basement geometry and drainage, sediment supply and sediment texture. This variability of the process, setting and the developmental frameworks may give rise to complex sand barrier-lagoon associated estuarine infill systems [2,3]. Thom [4] and Eliot [5] have stressed the great variety of morphologic, stratigraphic and dynamic patterns associated with the development of sand barriers.

The bight of Benin coast in West Africa (Fig. 1) exhibits one of the longest beachridge barrier-lagoon systems in the world. This system stretches virtually uninterrupted across a number of estuarine re-entrants for nearly $300 \mathrm{~km}$ from eastern Ghana to western Nigeria. Three prominent features relative to the development of this barrier system are: a sea level that has remained relatively stable, oscillating to within \pm 1 or $2 \mathrm{~m}$ of its present position since the highstand was attained around 5500 B.P.; the occurrence of several estuarine re-entrants along this

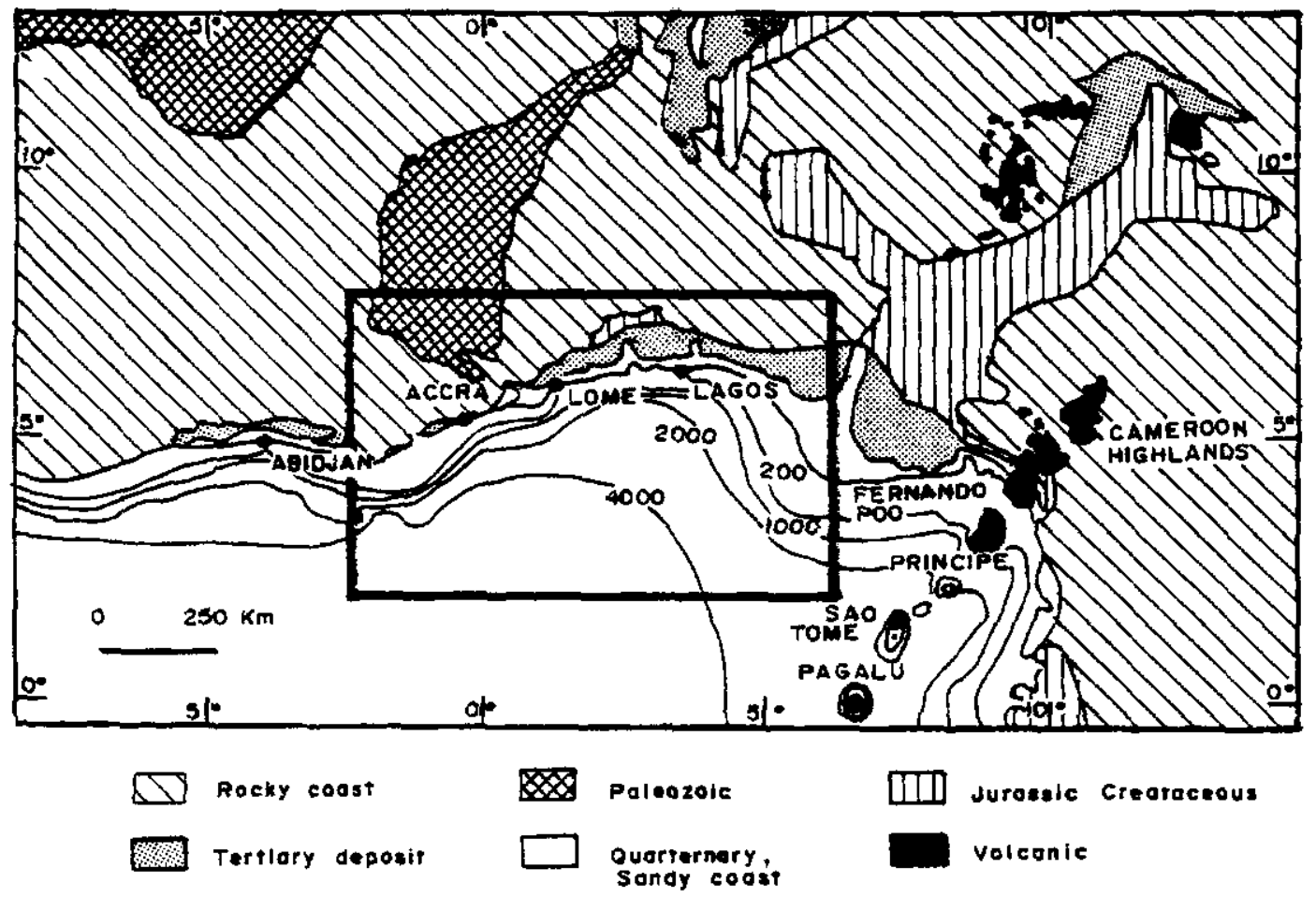

Fig. 1. The bight of Benin in West Africa coast. 
coast; a very strong eastward-directed longshore drift and the Volta delta, a major regional point source for sand supply to the littoral drift cell.

This paper describes the pattern of barrier development in response to these four conditions. This pattern shows points of similarity and differences with other regressive sand barriers described in the literature. Finally, the interpretations derived in this study are also relevant to the understanding of the recent and present coastal sediment dynamics of the entire bight of Benin coast, much of which is today subject to severe erosion that poses an important socio-economic threat to the already beleaguered economies of Ghana, Togo, Benin and Nigeria [6-10].

\section{Environmental setting}

The coastal deposits in the study area belong to a suite of Tertiary to Quaternary basin sediments. The older sediments, which outcrop as a coastal plateau, comprise two main entities: the "Continental Terminal", an unfossiliferous Mio-Pliocene formation of fluviatile and sheetwash sands, sandy clays and gravels [11,12]; and the "Terre de Barre", an equally unfossiliferous Early Quaternary deposit of fine quartz sands and kaolinite representing a siderolitic formation of sheetwash sediments eroded from lateritic soils upland [13].

The bight of Benin coast, oriented east-west, exhibits a broadly crescent-shaped planview pattern. This orientation reflects the main regional structural controls on the coastal margin. The east-west trending structures have limited shelf width, favouring the elaboration of a transform margin bounded by a narrow shelf, 15 $33 \mathrm{~km}$ wide. Width differences basically reflect slight left-lateral offsetting of the shelf by a number of east-west trending faults. Additionally, north-south coastperpendicular structures have played a determining role in the dissection of the coastal plateau and in the orientation of the more or less short coastal rivers. These structures are responsible for the east-west alternation of plateau bands and rectangular coastal re-entrants which have been tentatively interpreted, respectively, as horst or semi-horst and graben structures [14]. The Quaternary deposits within the re-entrants attain a thickness of up to $150 \mathrm{~m}$, reflecting several cycles of regressive and transgressive sedimentation [15]. Sediment sequences associated with the last regressive/transgressive cycle attain a thickness of up to $45 \mathrm{~m}$ collation of radiocarbon dates in West Africa published in the literature shows rates of sealevel rise as high as $1.6 \mathrm{~cm} \mathrm{a}^{-1}$ in the early Holocene, slowing down to around $0.8 \mathrm{~cm} \mathrm{a}^{-1}$ before stabilizing at around 5500 B.P. [16,17]. The sea-level trend since this time appears to have been characterized by a stable to slightly recessive trend punctuated by a number of minor oscillations $( \pm 1-1.5 \mathrm{~m})$.

The extensive lagoonal and lacustrine system is fed directly by several rivers with moderately sized catchments. River discharge is very low during the dry season months from December to May, but increases dramatically in the wet season, leading to water level rise in the lakes and lagoons. The most important river, the Volta, drains a wide variety of terranes covering an area of $390000 \mathrm{~km}^{2}$ (Fig. 2). The sand load brought down annually by this river is re-distributed alongshore via a 


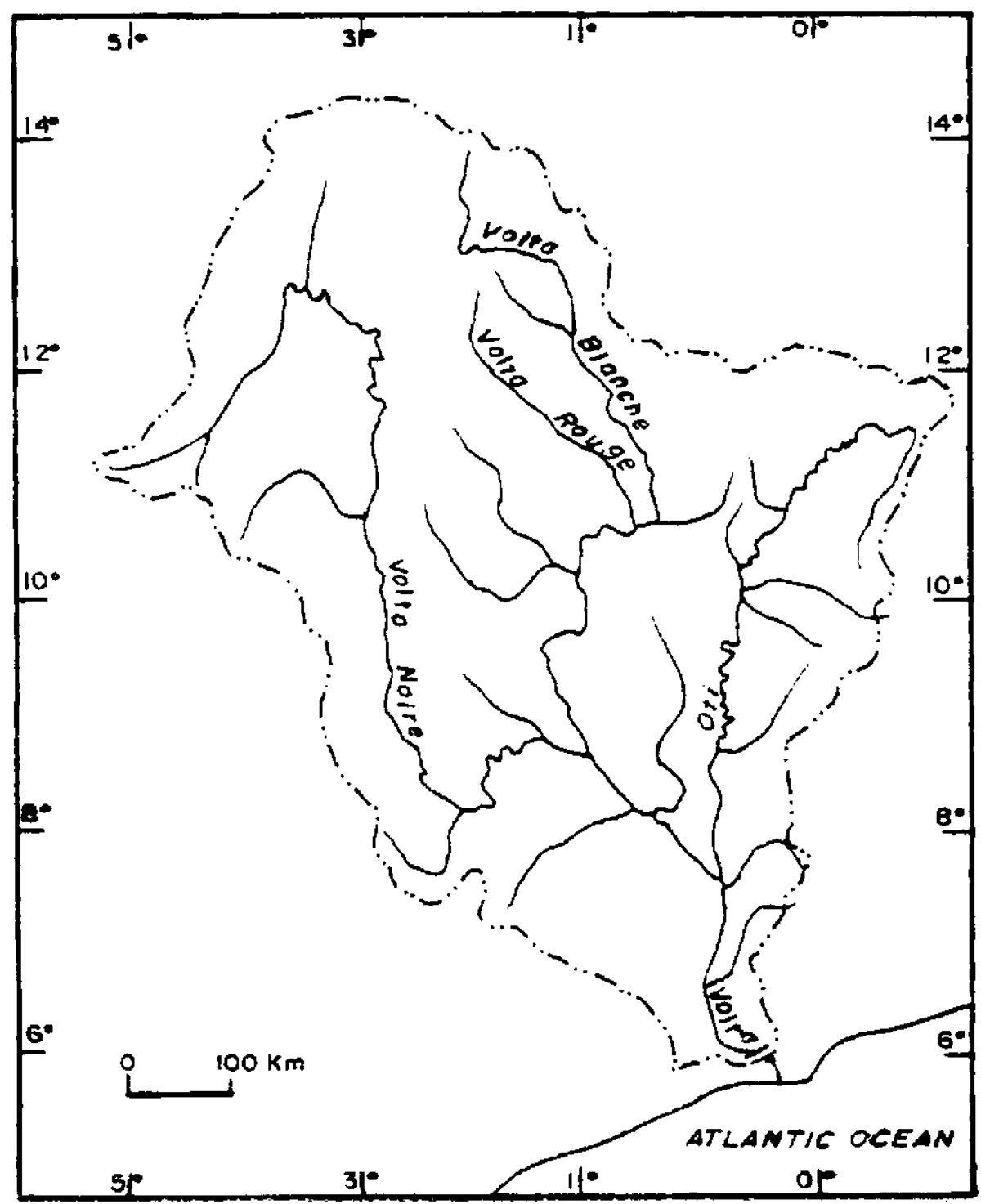

Fig. 2. Hydrographic basin of river Volta.

single delta channel, and attains up to 1 million $\mathrm{m}^{3}$. The Ouémé and the Mono, having respectively the second and third largest catchments, have an annual solid discharge of about 2 million and 1.3 million tonnes, respectively. The Mono, the only other river, apart from the Volta, that supplies sand directly to the coast, supplies an estimated $100000 \mathrm{~m}^{3}$ of sand to the sea during the wet season months, supplementing the massive sand load transported by longshore drift along the Togolese coast.

The bight of Benin coast is a cyclone and storm-free West Coast Swell Environment [18]. It is exposed throughout the year to constant, low to moderate energy $(H=0.5-1.5 \mathrm{~m})$, long period $(T=10-15 \mathrm{~s})$ southwesterly swells from the Atlantic. Swell energy increases from June to October with moderate to high-energy 
$(1.5-4 \mathrm{~m})$ waves $[19,20]$. Waves break on the coast of Benin after refraction, with an angle of 4 to $9^{\circ}$, and a mean of $6-7^{\circ}$. There is a subtle west-east variation in coastal orientation [6] which induces a slightly lower incident breaker angle towards the east. Wave height records also show a slight increase in this direction, thus maintaining the drift volume. Overall, the constant wave regime of this coast, marked by long, moderate to high waves and a hardly varying direction of approach, results in one of the highest rates of annual unidirectional longshore sand drift in the world, with maximum values of the order of 1.2-1.5 million $\mathrm{m}^{3}$ between Lomé in Togo and Cotonou in Benin and decreasing progressively towards the Nigerian border [6-8].

The bight of Benin coast is fronted by a fairly uniform, moderately steep shoreface with a gradient of between $1: 120$ and $1: 150$. Beyond $-15 \mathrm{~m}$, considered as the closeout depth for significant wave movements $[6,7]$, the inner shelf levels out to a lowgradient $(1: 350-1: 400)$ plain characterized by a cover of relict transgressive sands. Tides impinging on this coast are semi-diurnal, with a mean range of around $1 \mathrm{~m}$. The mean maximum spring tidal range is about $1.95 \mathrm{~m}$.

\section{Data acquisition}

The work summarized here has involved extensive field surveys and sediment sampling shallow coring, and data from numerous boreholes sunk in both the barrier sands and the estuarine and lagoonal deposits. Investigations have included grainsize and light and heavy mineral analyses of the sand fraction. The sedimentological analyses and stratigraphic interpretations were completed by analysis of plan-view barrier patterns from maps and aerial photographs and by field observations and measurements on such miscellaneous factors as beack-ridge morphology, present sedimentary processes and beach morphodynamics. Systematic levelling of the barriers has been carried out but a reasonable cover of spot heights exists from landuse documents on the beach ridges where settlement density is high. Existing ${ }^{14} \mathrm{C}$ dates, most of which come from the estuaries in Benin $[21,22]$ have been used in a broad determination of the time frame of development of the sand barriers.

\section{Coastal plain morphology}

The "Terre de Barre" formation is generally in contact with the barrier-lagoon systems and re-entrant infill. In places, this contact is marked by abandoned cliffs. The sand barrier system is complex and comprises one to three different barriers that may be clearly distinguished on the basis of geographic extent, petrographic characteristics and soil development (Fig. 3a-c). In places, only one barrier is present, where as elsewhere, one or two more barriers exist separated by lagoonal arms. Each barrier exhibits several beach ridges standing 3-6 m above present mean sea level. These beach ridges have been highly degraded in places. Beach ridge tips of the inner barriers commonly end in swampland or open water as recurved spits. The outer barrier beach ridges run uninterrupted from the Volta delta in Ghana to Lagos 


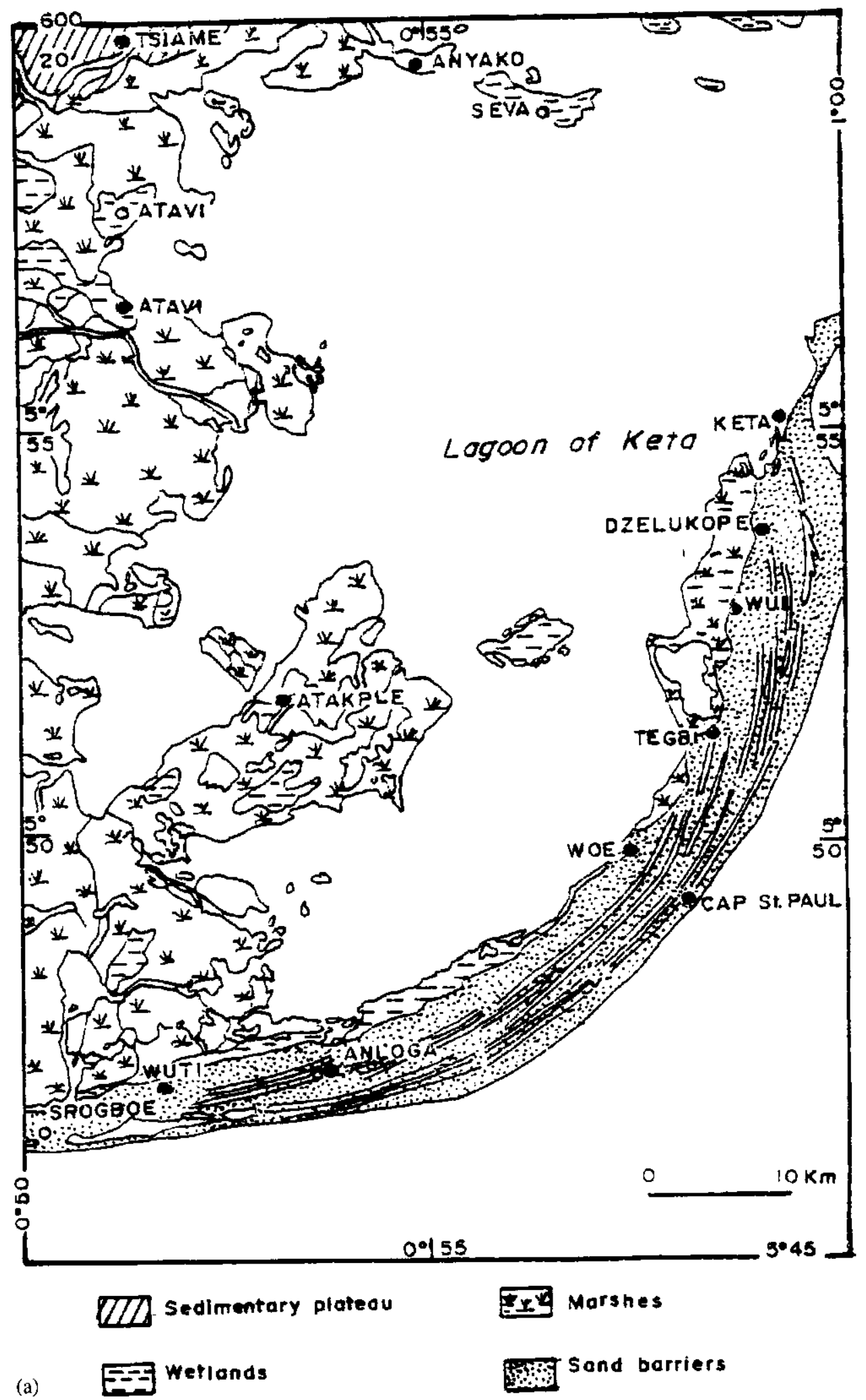

Fig. 3. (a) Coastal morphology, south-east of delta Volta. (b) Togo, coastal morphology : from Keta lagoon to Aneho. (c) Coastal morphology of east side of Benin. 


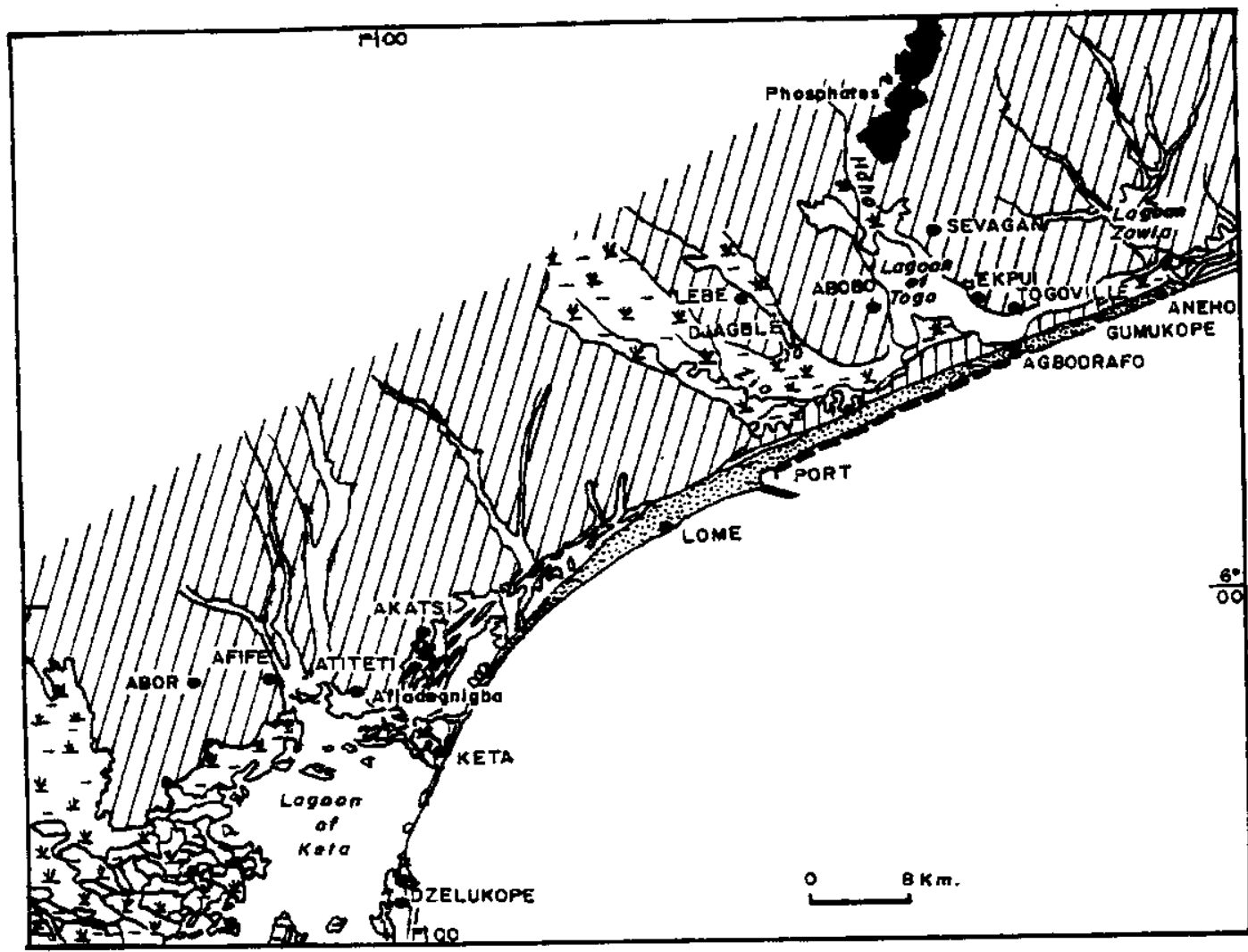

outer borrier

ULi pioteou

(b)
DII] Inner sorrier

Wettonds and marshes

Lagoon.

Fig. 3 (continued).

in Nigeria, dissected by only two natural and one artificial inlets. These inlets function as river and lagoonal outlets during the wet season when river discharge is high and as tidal inlets the rest of the year. The Aneho inlet in Togo is often sealed by longshore drift, while the Boca del Rio inlet in Benin, which has a bigger crosssectional area and is fed by a bigger tidal prism landward, generally stays open throughout the year. The man-made outlet, cut across the outer barrier in the Cotonou area in 1885 (Fig. 4) and artificially kept open since, links the So-Ouémé estuary with the sea [23]. From Lagos to the Niger Delta, the barriers segments are much shorter, interrupted by numerous tidal inlets and delta distributary outlets $[24,25]$.

\section{Barrier and shoreface sands}

The barrier sands vary in thickness from $<5 \mathrm{~m}$ inland to at least $20 \mathrm{~m}$ seaward. Beach and foreshore facies form a 5-8 $\mathrm{m}$ thick unit of coarse to fine sand that grades 


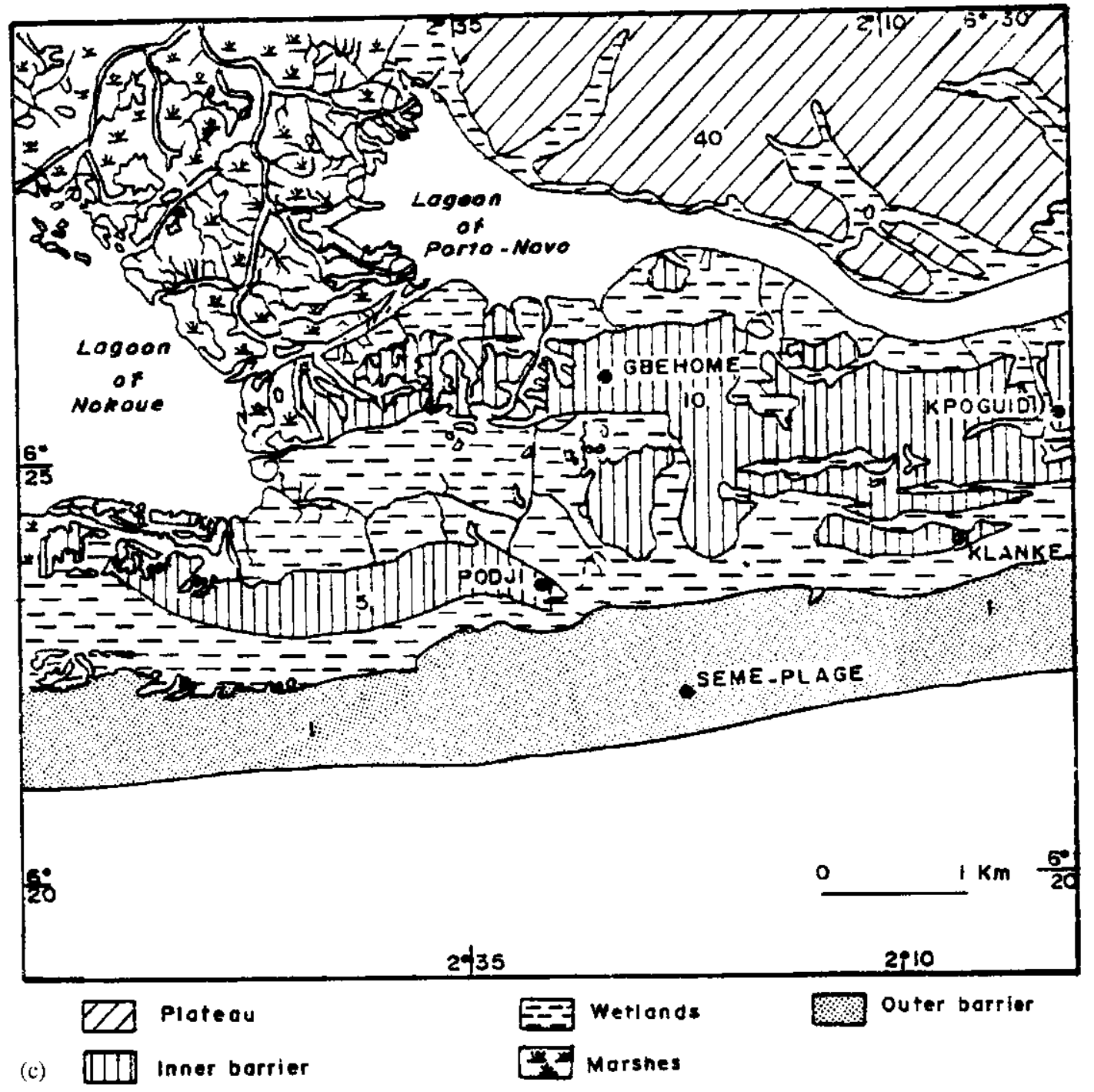

Fig. 3 (continued).

downwards into shoreface facies of interbedded fine sand and silt. The older inner barrier/shoreface sands rest either directly on the Late Pleistocene surface, with a sharp erosional contact, or, with a sharply gradational contact, on lagoonal/ washover muds and estuarine shoal sand, depending on location. The outer beachridge/shoreface sands generally form a seaward thickening wedge that merges.

Radiocarbon dates from these highly quartzose barrier and shoreface sands are few. The available dates [23], the stratigraphic relationship of these barriers to the dates obtained from both the Pleistocene basement and lagoonal, tidal inlet and estuarine re-entrant muds and sands, and the degree of soil development of the barrier beach-ridges suggest a middle Holocene to recent age. A possible exception might be that of the innermost barrier in Benin, the only sector where three distinct 


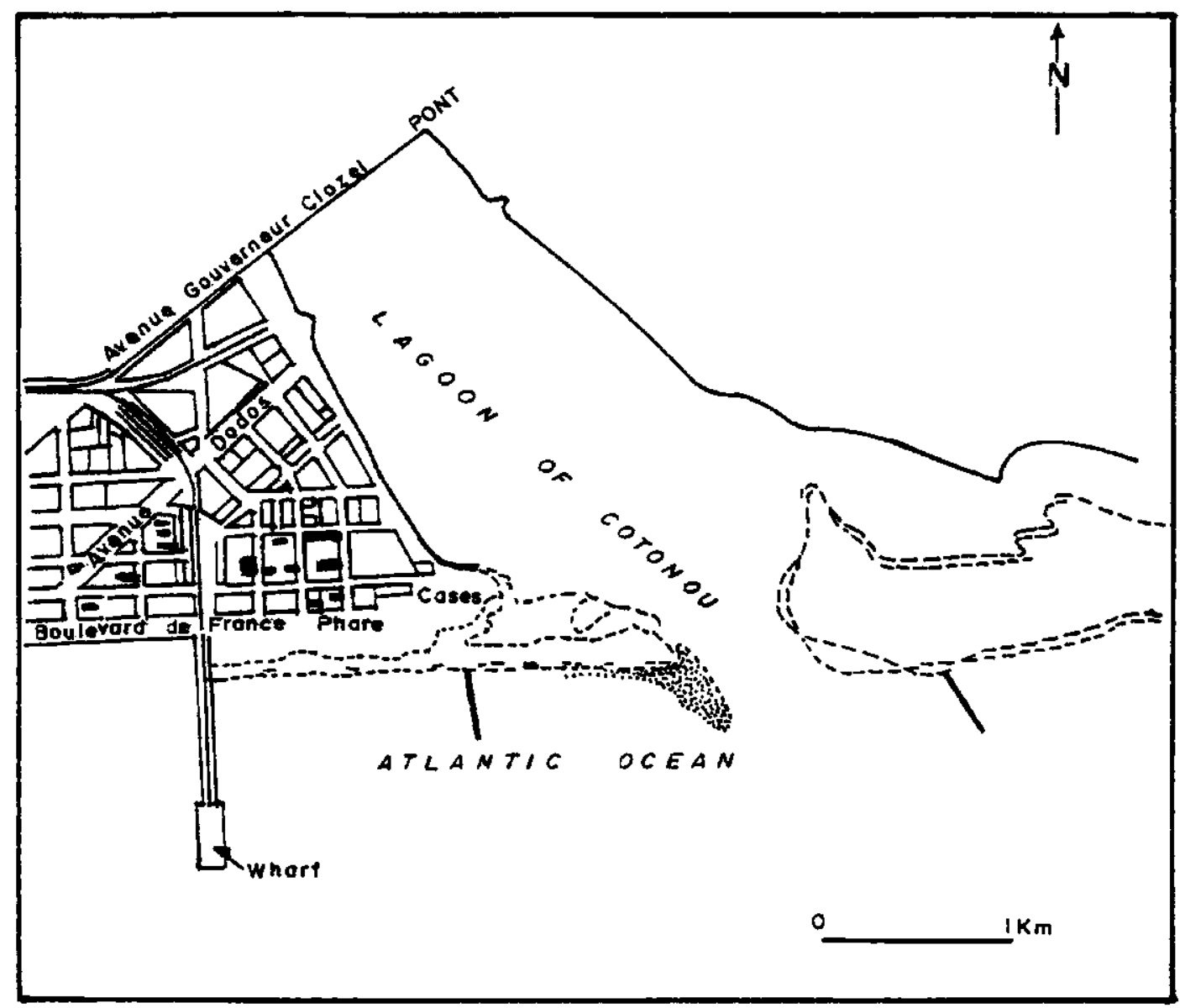

Fig. 4. The mouth of lagoon of Cotonou (Benin).

barriers exist. This barrier might be a vestige of an Eemian barrier system emplaced during the last eustatic highstand at around $100000 \mathrm{yr}$ B.P. The use of new radiometric dating methods of quartz sands such as thermoluminescence dating should help in clarifying the age structure of his innermost barrier. The few dates from the other barriers show a downdrift "younging" trend from Togo to Benin, whose significance will be discussed later.

\section{Barrier development}

The gross barrier morphology, the beach-ridge patterns, the barrier stratigraphy and the available radiocarbon dates suggest a basically two-stage framework of development: formation of a segmented inner barrier system; formation of a quasicontinuous outer barrier from the Volta delta to Nigeria; long-term quasi-stability of this outer barrier system and recent breakdown and barrier destabilization. 


\subsection{Inner barrier development}

The inner barrier shows a segmented pattern of development that may be related to the influence of the inherited coastal morphology, characterized by several infilling coastal re-entrants. These no doubt induced a polycellular longshore drift system characterized by several cells rather than the integrated single cell that prevailed up to recently [26]. Both the plan-view pattern and the geographic extent of these inner barriers suggest a segmented sand supply system. Neither the beach-ridge patterns nor the petrographic characteristics of these barrier sands suggest sourcing by the Volta delta which at this time was building up its delta. This inner barrier developed over relatively shallow estuary-mouth subtidal shoals, through successive eastward progradation of spits that progressively closed off the Zio and Haho estuaries in Togo and the Mono and Couffo estuaries in Benin. The shallow nature of this substrate suggests substantial aggradation from sands eroded from coastal and shoreface outcrops of poorly consolidated Late Pleistocene sediments and advected eastwards by longshore drift. The cliffs that bound much of the coastal plateau in this sector were probably related to this phase of coastal development, actively supplying sands for downdrift spit progradation across the shallow estuary-mouth shoals. These barriers consist of medium to fine ironcoated carbonate-free sands. The heavy mineral suite is highly diversified, but is dominated by iron concretions such as limonite and worn ubiquitous minerals, notably zircon, tourmaline, rutile, sphene and disthene suggesting sourcing by mature, weathered coastal and nearshore sedimentary sources. Quaternary Volta delta sediments on the shoreface and inner shelf [27] have also constituted a significant source, as can be seen from the beach-ridge pattern adjacent to the delta (Fig. 5).

Further downdrift, in Benin and Nigeria, along slightly embayed sectors of "headland" coast between estuaries, the inner barrier sands rest on continental sheetwash deposits and show only rather timid intrusion towards the estuaries, widening towards the So-Ouémé estuary in response to increasing refraction. These inner barriers left wide open this estuary in particular, which has been shown to have functioned as a ria at least up to 3900 B.P. [10]. Spit progression across the estuary was probably constrained by the moderate sediment supply from the nearshore zone and locally eroded cliffs updrift, and by the existence of deeper estuary-mouth shoals. The erosional surface between these barrier sands and the underlying Late Pleistocene fan deposits suggests "ravinement" processes and in situ reworking of the latter. Holocene barrier deposits commonly exhibit a suite of facies that may include washover and lagoonal muds and sands that generally rest on the Pleistocene $[4,5,28]$. In this sector of the bight of Benin coast, lagoonal/washover muds and muddy sands are absent under the barrier sands, presumably destroyed through this in situ reworking as sea-level rise slowed down towards the middle Holocene and barrier progradation started. Progradation occurred the formation of beach ridges from wave-winnowing of shoreface facies and onshore/longshore transport of sands, probably aided by a slow fall in sea-level in West Africa following the post-glacial maximum [17]. 


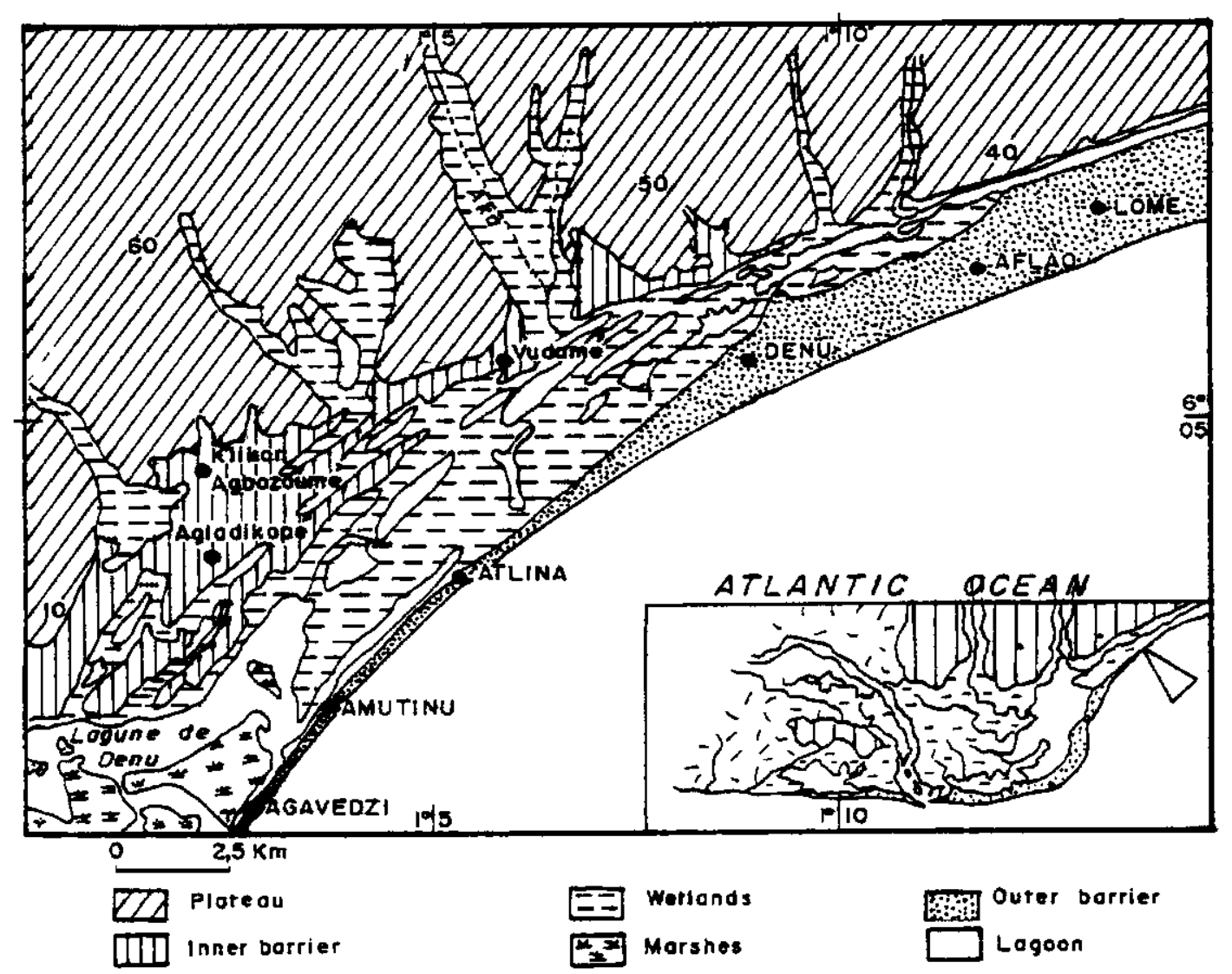

Fig. 5. Coastal morphology: development of sand barrier from the east side of delta Volta.

In the Mono-Couffo sector, the inner barrier has been considerably dissected by migration of fluvio-lagoonal channels and tidal inlets. The contact between floodtidal inlet/subtidal shoal sands in this sector is very shallow, suggesting joint development of these two units within a net progradational framework. Because of the moderate nature of the sand inputs for barrier progradation, tidal inlets have been maintained and have contributed, together with migration of lagoonal and tidal channels in dissecting the barrier. Such channel migration is a by-product of the advanced infill of wave-dominated estuaries.

\subsection{Outer barrier progradation}

The outer barriers form moderately thick sand sheets that have prograded on to the inner shelf. They form two contiguous segment. The first is attached to the mouth of this river, and is linked through a major longshore drift corridor to the second much longer barrier that stretches up to western Nigeria, over $220 \mathrm{~km}$ of coast. Outer barrier formation is an outgrowth of three joint factors: aggradation of estuary-mouth deposits in the Volta delta, thus allowing for supply of excess sand to 
the longshore drift system; infill of the small estuarine re-entrants in Togo and the Mono estuary in Benin and retreat of mildly projecting soft coastal "headlands" between estuaries. These three conditions have allowed for through drift of massive sand supplies from the Volta delta for barrier progradation.

The sands supplied by the Volta are texturally and mineralogically distinct from those of the inner barrier. They are coarse to fine, subangular to subrounded quartz sands, but commonly include fine gravel fragments from a wide variety of crystalline source rocks. The heavy mineral fraction is dominated by easily weatherable minerals, especially garnet, epidote and green hornblend $[8,15]$. Occasional glauconitic grains may reflect a contribution from the nearshore zone [29]. The mean diameter of the beach-ridge sands shows downdrift fining away from the Volta source, before stabilizing. This pattern is interrupted in a few areas where grain size increases sharply downdrift over a few kilometers [7]. Such areas correspond to portions of coast cut by tidal inlets/stream outlets.

Differences in progradation of the outer barrier reflect more or less subtle variations in past longshore drift gradients alongshore, determined in turn by coastal configuration following formation of the inner barrier. Barrier width increases towards Benin, especially at the So-Ouémé estuary mouth whose final infill has involved the emplacement of successive flared spit ridges, representing massive sediment inputs from alongshore. Inner spit formation was succeeded by the emplacement of parallel beach ridges representing net regressive barrier growth. Overall, the outer barrier thickens and widens eastward towards the Nigerian border, in response to past and still present subtle positive gradients in longshore drift induced by the regional west to east decrease in wave breaker angles along this bight coast.

Radiocarbon dates obtained from beach and shoreface shell beds and beach rock exposed by recent coastal erosion $[23,30]$ show a phased pattern of progradation from west to east. Progradation ceased around 3800 B.P. in Togo and around 2000-1500 B.P. In Benin, in spite of the massive volume of sand drifting alongshore. The ensuing phase of long-term stability probably stemmed from some sort of equilibrium involving shoreline orientation, the nearshore profile and the hydrodynamic regime. In terms of sand transport in the coastal zone, this situation installed a long-term balance between incoming and outgoing sand along much of the bight coast. It represents a classic example of Davies [8] "equilibrium driftalignment". Earlier achievement of this alignment in Togo was no doubt the result of a more favorable initial bight configuration, propitious to beach-ridge deposition, and of proximity to the Volta sand "pump". The radiocarbon dates from Benin suggests that much of the barrier progradation in this downdrift sector occurred massively following cessation of progradation of the updrift Togo coast. The spit ridges in the Cotonou area show evidence of breaching in places. This is probably related to sediment starvation as a result of an updrift beach-ridge system that was maturing while still sequestering sands from the Volta. The development of the bight of Benin beach ridges has been characterized by the progressive downdrift migration of the accumulation sector as equilibrium was achieved updrift. The "excess sand wave" shifted eastward to feed first the So-Ouémé sector, and finally the 
Benin-Nigeria border sector up to and beyond Badagri, where there is evidence for ongoing progradation [11].

The bight of Benin barrier-front has undergone cycles of minor erosion or progradation, as attested by analysis of ancient maps and reports and more recent documents $[5,6]$. These events reflect occasional negative or positive longshore sediment budget gradients. The causes may be multiple and include sand supply fluctuations from the Volta, changes in the location of the Boca del Rio inlet, direct breaching by the Mono, sea-level fluctuations or minor variations in wave approach direction associated with changes in Central and South Atlantic storm belts, wind setup related to impinging southwesterly winds, meteorologically forced steric changes in impinging water mass characteristics, etc. However, net stability has the norm on this coast.

This situation of relative long-term equilibrium on the Togo and Benin coasts has been perturbed by recent dam and coastal installations. The construction of the

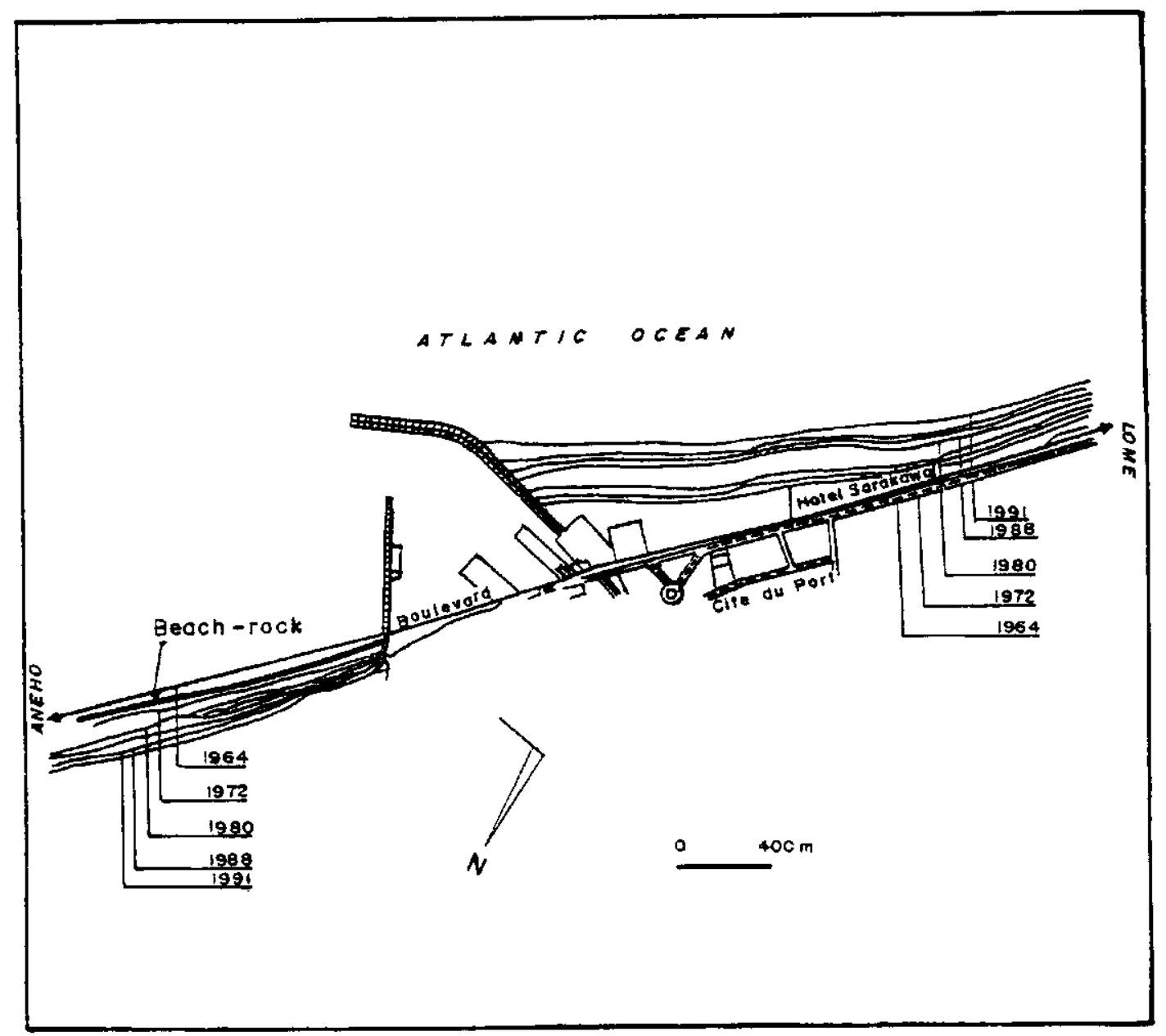

Fig. 6. The port of Lome; evolution of the coastline. 


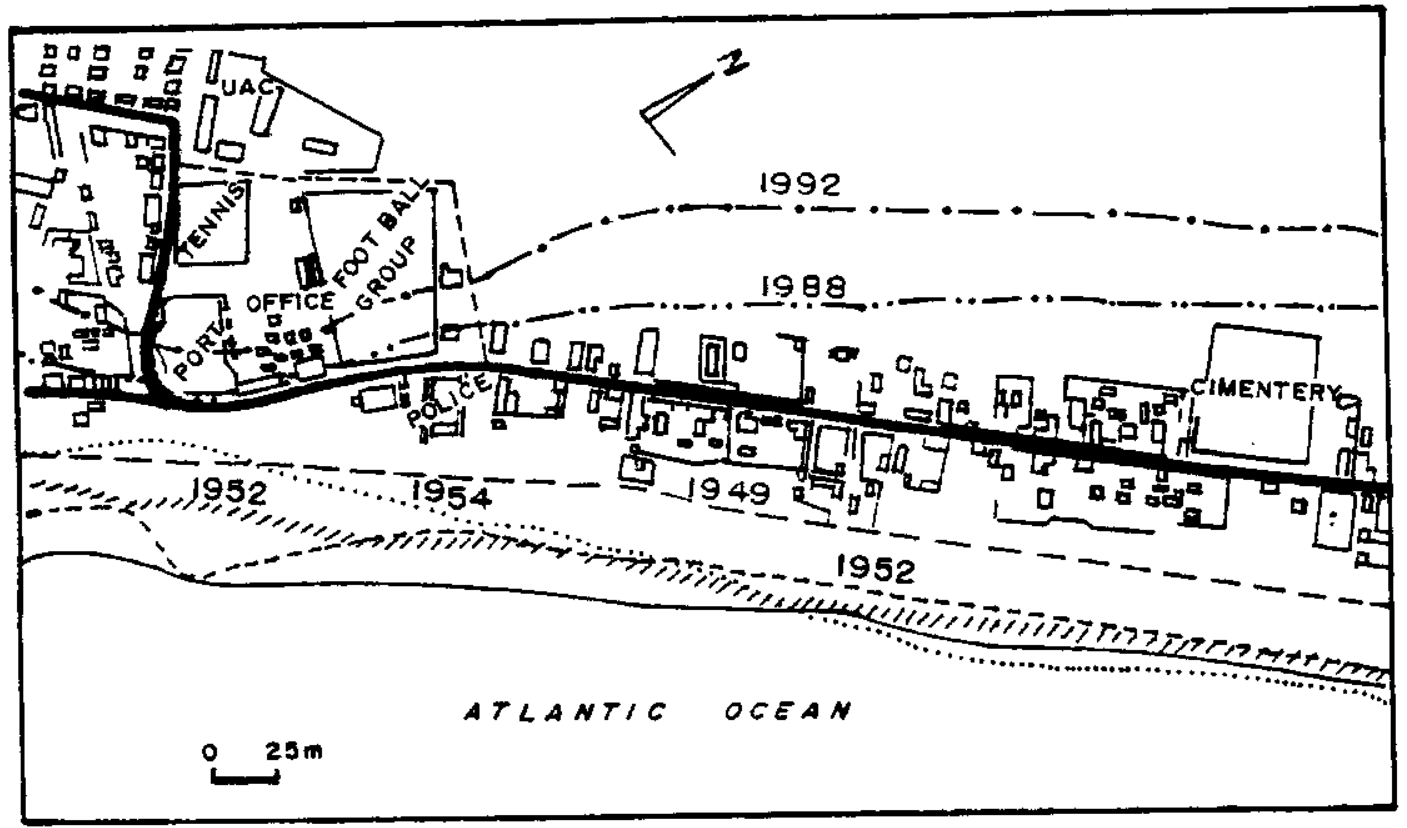

Fig. 7. Coastal dynamic: the retreat of the shoreline at Keta (Ghana).

Akosombo dam on the Volta river in 1960 resulted in a dratic reduction in sand supply to the bight of Benin coast [24], while the two deepwater ports of Cotonou and Lomé, respectively, inaugurated in 1962 and 1967 (Fig. 6), have led to segmentation of the littoral drift cell. Present barrier beach dynamics are characterized by three types of behaviour: massive progradation of stretches of beach downdrift of the port breakwaters which stop sand drifting alongshore; erosion, at rates of up to $10 \mathrm{~m} / \mathrm{yr}[5,6,24,25]$, of updrift sectors (Fig. 7); relative stability, within a dynamic framework of irregular phases of cut and recovery that includes various time frames, ranging from seasonal to pluri-annual.

\section{Conclusion}

This paper has examined the stratigraphic characteristics and patterns of morphosedimentary development of coastal sand barriers on the bight of Benin, West Africa. The analysis shows that the initial control on barrier development was vested in drowned estuaries which modulated patterns of wave refraction alongshore, leading in particular to the formation of a segmented inner barrier system, separated by sectors of eroding cliffs or open estuary mouths. Sediment sources were local, essentially the nearshore zone and eroding chiffs. The Volta delta does not seem to have been as significant a source as it was to become later. With aggradation of this delta, excess sand was supplied more massively to the longshore drift system. Once estuaries were barred off by the inner barrier and projecting cliff sectors were cut 
back, the establishment of a unicellular longshore drift system fed by this delta has allowed for the formation of a thicker, continuous outer barrier in front of the inner segmented one. This process of alongshore drift feeding of sand has also entailed substantial aggradation of the shoreface which has constituted a platform for outer barrier progradation. Although the sand supply volume alongshore has remained consistently high, progradation has diminished considerably or ceased as an equilibrium "drift alignment" allowing for sand by passing alongshore towards Nigeria has been achieved. Sediment supply alongshore and rates of progradation or shoreface aggradation may have been modulated by various factors, notably sealevel oscillations, the role of which is presently being investigated, especially as regards the formation of beach-ridge sets and the shift from spit-type development to parallel beach-ridge formation. On this strongly drift-aligned coast, the construction of deepwater ports in the last three decades has led to segmentation of the hitherto unidirectional drift, with sectors of massive erosion updrift of the breakwaters alternating with sectors of equally massive and spectacular progradation downdrift and with sectors of relative stability.

\section{References}

[1] Hayes MO. Barrier island morphology as a function of tidal and wave regime. In: Leatherman SP, editor. Barrier Islands. New York: Academic Press, 1979. p. 1-27.

[2] Kraft JC, et al. Processes and morphologic evolution of an estuarine and coastal barrier system. In: Leatherman SP, editor. Barrier Islands. New York: Academic Press, 1979. p. 149-83.

[3] Roy PS, et al. Holocene sequences on an embayed high-energy coast: an evolutionary model. Journal of the Geological Society of Australia 1980;28:471-89.

[4] Thom BG. Sand barriers of eastern Australia: Gippsland-a case study. In: Thom BG, editor. Coastal geomorph in Australia. Sydney: Academic Press, 1984. p. 233-61.

[5] Eliot IG. Seasonal and biennial fluctuation in sub-aerial beach sediment volume on Warilla beach, New South Wales. Marine Geology 1982;48:89-103.

[6] Eec Report, Erosion côtière dans le Golfe du Bénin. Aspects nationaux et régionaux. Direction générale du développement, 1989.

[7] Rossi G. L'érosion du littoral dans le Golfe du Bénin: un exemple de perturbation d'un équilibre morphodynamique. Zeitschrift fuer Geomorphologie, NF Supplementband 1989;73:139-65.

[8] Blivi A. Géomorphologie et dynamique actuelle du littoral du Golfe du Bénin (Afrique de l'Ouest) PhD thesis, Université Michel de Montaigne, Bordeaux, 1993a, 458p.

[9] Blivi A. Morphology and current dynamics of the coast of Togo. Geo-Eco-Trop 1993;17:25-40.

[10] Anthony E, Blivi A. Morphosedimentary evolution of a delta-sourced, drift-aligned sand barrierlagoon complex, western Bight of Benin. Marine Geology 1999;158:161-76.

[11] Lang $\mathbf{J}$, et al. Le sidérolithique du Tertiaire ouest-Africain et le concept de Continental terminal. Bulletin for the Society of Géology of France 1986;8:605-22.

[12] Lang $\mathbf{J}$, et al. Le domaine margino-littoral du Bénin (Golfe de Guinée-Afrique de l'Ouest): age Holocène et mise en place marine des sables jaunes. Journal of the African Earth Science 1989;9:3813.

[13] Houessou A, Lang J. La terre de barre dans le Bénin méridional (Afrique de l'Ouest). Bulletin ASEQUA 1979;56-57:49-59.

[14] Lang J, Paradis G. Un exemple d'environnement sédimentaire bio- détritique non carbonaté marin et continental, holocène, en climat intertropical: le domaine margino-littoral du Bénin méridional (ex dahomey). Revue Géographie Physique et de Géologie Dynamique 1977;19:295-312. 
[15] Oyede LM. Dynamique sédimentaire actuelle et messages enregistrés dans les séquences quaternaires et néogènes du domaine margino-littoral du Bénin (Afrique de l'Ouest). Thèse de DoctoratGéol.Marine, Université de Bourgogne-Université Nationale du Bénin, 302p. 1991.

[16] Anthony E. Chenier plain development in northern, Sierra Leone (West Africa). Marine Geology 1989;90:255-8.

[17] Anthony E. Beach-ridge plain development, Sherbro Island, Sierra Leone. Zeitschrift fuer Geomorphologie, NF Supplementband 1991;81:85-98.

[18] Davies JL. Geographical variation in coastal development. 2nd ed. London: Longman, 1980. 212p.

[19] Guilcher A. Dynamique et morphologie des côtes sableuses de l'Afrique Atlantique. Cahiers d'Info Géog 1954:1:57-68.

[20] Sitarz J. Còtes Africaines - étude des profils d'équilibres des plages. Travaux de Centre de Recherches et d'Etudes Océanographiques 1960;3:43-62.

[21] Germain P. Contribution à la connaissance du quaternaire récent du littoral dahoméen. Bulletin ASEQUA 1975;44-45:33-45.

[22] Paradis G. Observations sur l'holocène récent du Sud-Bénin (ex Sud-Dahomey). Bulletin ASEQUA $1977 ; 51: 49-81$.

[23] Lang J, Paradis G. Le Quaternaire margino-littoral béninois (Afrique de l'Ouest). Synthèse des datations au Carbone 14. Palaeocol African and Surrounding Islands 1984;16:65-76.

[24] Guilcher A. Observations comparatives sur un complexe littoral de la côte Atlantique Africaine. Norois Poitiers 1978;100:55I-6.

[25] Usoro EJ. Nigeria. In: Bird ECF, Schwartz ML, editors. The World's Coastline. New York: Van Nostrand Reinhold Co., 1985. p. 607-19.

[26] Blivi A. Le delta de la Volta; de l'Holocène à l'Actuel. Ann. University Bénin, Sér. Lett. Tome XV 1995;109-125.

[27] Dei LA. The central coastal plains of Ghana. A morphological and sedimentological study. Zeitschrift fuer Geomorphologie, NF Supplementband 1972;16-4:415-31.

[28] Kraft JC. Sedimentary facies patterns and geologic history of a Holocene marine transgression. Geological Society of American Bulletin 1971;82:2131-58.

[29] Ly CK. The role of Akossombo dam on the Volta river in causing erosion in central and eastern Ghana (West Africa). Marine Geology 1980;35:323-32.

[30] Amieux P, et al. Cathodoluminescence of carbonate-cemented holocene beach-rock from the Togo coastline (West Africa): an approach to early diagenesis. Sedimentary Geology 1989;65:261-72. 